\title{
GEMA KITAB KEJADIAN DALAM \\ 1 KORINTUS 11:7-9
}

\author{
Liu Wisda
}

\begin{abstract}
Abstrak: Beberapa pendekatan telah dilakukan, seperti pendekatan teologis, analisa kultural, dan konteks historis untuk mengerti 1 Korintus 11:3-16 tentang kesopanan perempuan dalam ibadah. Tulisan ini berusaha mengerti teks ini melalui pendekatan intertekstual yang menggarisbawahi penggunaan kitab Kejadian dalam retorika Paulus (1 Kor. 11:7-9) yang mewajibkan perempuan memakai kerudung dalam ibadah.
\end{abstract}

Kata Kunci: Intertextuality, Narrative Summary, 1 Korintus 11:79, Gambar dan Kemuliaan Allah, Kemuliaan Laki-laki, Urutan Penciptaan

\begin{abstract}
Attempts have been made to understand 1 Corinthians 11:7-9 regarding the women propriety in worship, such as theological approach, cultural analysis, and historical context. This article attempts to understand the text by the intertextual approach, which hightlights Paul's use of Genesis texts as a part of his rhetoric of why women must cover their heads in worship.
\end{abstract}

Keywords: Intertextuality, Narrative Summary, 1 Corinthians 11:7-9, Image and Glory of God, Glory of Man, Creation Order

\section{PENDAHULUAN}

Dalam menghadapi persoalan tentang kesopanan perempuan dalam beribadah (1 Kor. 11:3-16), Paulus menggunakan teks kitab Kejadian untuk mendukung argumennya dalam mewajibkan perempuan menutup kepalanya di dalam ibadah. Pernyataan Paulus 
tampaknya mengekspresikan subordinasi kaum perempuan (pria sebagai pemimpin berotoritas atas perempuan); pernyataan tersebut kerap kali dijadikan argument definitif oleh pihak golongan Kristen tradisional. Akan tetapi, di dalam surat 1 Korintus sendiri, tampaknya ada indikasi bahwa pernyataan Paulus bertentangan dengan argumentasinya sendiri, yaitu argumentasi yang menekankan kesetaraan laki-laki dan perempuan, seperti referensi pada tubuh Kristus yang menjelaskan semua anggota adalah satu di dalam Kristus (1 Korintus 12:13; bdk. Galatia 3:28). ${ }^{1}$ Selain itu, penyebutan Akwila dan Priskila (suami istri) yang sama-sama melayani merupakan contoh adanya (indikasi) kepemimpinan perempuan di kalangan orang Kristen (1 Korintus 16:19). ${ }^{2}$ Tambahan pula, para penganut egalitarian (persamaan gender) berargumen bahwa argumentasi Paulus dari urutan penciptaan tersebut didasarkan pada masalah budaya lokal, yang berbeda dengan budaya di zaman sekarang dan lokasi (budaya menudungi kepala), sehingga jawaban Paulus itu hanya relevan pada masalah lokasi yang berkaitan dengan budaya mereka saat itu. ${ }^{3}$

\section{Alih-alih mengkritisi pemahaman-pemahaman yang disebutkan di atas, penulis menggunakan pendekatan}

\footnotetext{
${ }^{1}$ Galatia 3:28 (lebih ekspresif: laki-laki dan perempuan) yang dianggap menekankan kesetaraan dan kesatuan mereka di dalam Kristus Yesus.

2 Meskipun kita tidak bisa menentukan level atau seberapa besar pengaruh kepemimpinan Priskila bersama suaminya, Paulus mengakui bahwa mereka adalah misionaris yang menjadikan rumah mereka sebagai gereja dan menjadi rekan pelayanan Paulus yang penting. Lih. Peter Lampe, "Prisca" in The Anchor Bible Dictionary, ed. David Noel Freedman (New York: Doubleday, 1996, c1992), 5:467-468.

${ }^{3}$ Contoh pendekatan budaya adalah "redemptive-movement hermeneutic" yang dipopulerkan oleh William J. Webb, yang memahami Alkitab dengan mencari "semangat" dari (gerakan penebusan) redemptive movement dalam teks untuk melihat apa yang bisa diaplikasikan hari ini. Asumsinya adalah mengubah umatNya selangkah demi selangkah sesuai dengan konteks masa kini, sehingga ada teks yang berlaku dan ada yang tidak berlaku. Contohnya sabat, sunat, hukum makanan, menstruasi dll di dalam PL. Lih. William J. Webb, Slave, Women and Homosexuals: Exploring the Hermeneutics of Cultural Analysis (Downers Grove, IL: IVP Academic, 2001).
} 
intertekstualitas ${ }^{4}$ untuk memahami 1 Kor. 11:7-9 (inti argumentasi Paulus yang didebatkan) dan menyimpulkan bahwa di dalam penggunaan teks Kejadian, Paulus menekankan perempuan yang menjadi kemuliaan pria, tanpa mengabaikan argumentasi hubungan hirarki berdasarkan urutan penciptaan. Tujuan Paulus dalam teks ini bukanlah untuk mendukung subordinasi kaum perempuan, tetapi memanggil para perempuan untuk mempraktikkan kasih Kristus di dalam komunitas yang memiliki budaya menutup kepala perempuan sebagai tanda kemuliaan. Karena itu, analisa intertekstual pada teks ini dikelompokkan ke dalam dua: ayat 7 dan ayat 8-9.

\section{Ayat 7}

Ayat 7 merupakan alasan dan argumentasi Paulus di ayat 4-5: seorang pria tidak seharusnya menutupi kepalanya (ayat 4), karena dia adalah gambar dan kemuliaan Allah (ayat 7a), sedangkan seorang perempuan seharusnya berkerudung karena dia adalah kemuliaan pria. Dengan asumsi bahwa jarang ada kata yang merupakan kreasi murni dari Paulus, ${ }^{5}$ pernyataan Paulus ini juga merupakan bagian dari dunia kata yang tidak asing dengan para pembaca. Di dalam periode bait suci kedua atau masa intertestamental, ada beberapa teks atau tradisi Yahudi yang memiliki ekpresi yang mirip di dalam ayat ini. Tabel berikut ini menggambarkan beberapa tradisi tersebut:

\footnotetext{
${ }^{4}$ Untuk definisi dan teknik pendekatan intertekstual, lihat Richard Hays, Echoes of Scripture in the Letters of Paul (New Haven, NH: Yale University Press, 1989).

${ }^{5}$ Pendekatan intertekstual mengasumsi bahwa semua kata yang diekspresikan penulis Alkitab memiliki relasi dengan kata lain, sehingga tidak ada makna baru bahkan di dalam kata yang diciptakan (hapax legomenon). Dengan bahasa Fishbane, content teks atau traditum tidaklah monolitis (memiliki satu arti tunggal), tetapi merupakan:" the complex result of a long and varied process of transmission, or traditio." Michael Fishbane, Biblical Interpretation in Ancient Israel (New York, NY: Oxford University Press, 1985), 6.
} 


\begin{tabular}{|c|c|c|}
\hline & Referensi Tidak Langsung & $\begin{array}{c}\text { Hubungan } \\
\text { Intertekstual }\end{array}$ \\
\hline $\begin{array}{c}\text { Frasa } \\
\text { pertama }\end{array}$ & 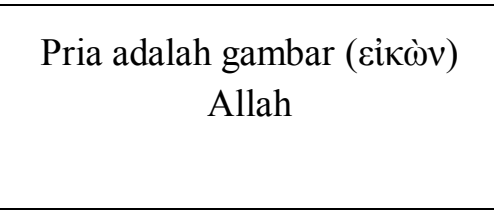 & $\begin{array}{c}\text { Kejadian 1:27; 2:7; } \\
\text { Sirakh 17:1-3; } \\
\text { Kebijaksanaan Salomo } \\
\text { 2:23; Tulisan para rabi }\end{array}$ \\
\hline $\begin{array}{l}\text { Frasa } \\
\text { kedua }\end{array}$ & $\begin{array}{c}\text { [Pria] adalah kemuliaan }(\delta o ́ \xi \alpha) \\
\text { Allah }\end{array}$ & Tulisan rabinik \\
\hline $\begin{array}{l}\text { Frasa } \\
\text { ketiga }\end{array}$ & 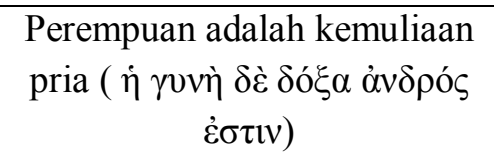 & $\begin{array}{l}\text { Amsal 11:16 LXX; } 1 \\
\text { Esdras 4:17; batu nisan } \\
\text { Yahudi di Roma. }\end{array}$ \\
\hline
\end{tabular}

Frasa pertama memiliki kemiripan ekspresi di dalam Kejadian 1:27 (Maka Allah menciptakan manusia itu menurut gambar-Nya, menurut gambar Allah diciptakan-Nya dia; laki-laki dan perempuan diciptakan-Nya mereka, dan 2:7 (ketika itulah TUHAN Allah membentuk manusia itu dari debu tanah dan menghembuskan nafas hidup ke dalam hidungnya; demikianlah manusia itu menjadi makhluk yang hidup). Di samping itu, sirakh ${ }^{6}$ dan kebijaksanaan Salomo ${ }^{7}$ juga menggunakan tradisi Kejadian ini di dalam ekspresi mereka.

Ketika Paulus mengatakan bahwa manusia adalah gambar Allah, dia mungkin mengungkapkan narasi yang diringkas dari Kejadian 1 melalui lensa Kejadian 2 yang menunjukkan bahwa Adam/manusia adalah karya ciptaan Allah secara langsung. ${ }^{8}$ Meier

\footnotetext{
${ }^{6}$ 17:1-3 "Manusia diciptakan Tuhan dari tanah, dan ke sana akan dikembalikan juga. Ia menganugerahkan kepadanya sejumlah hari dan jangka, dan memberinya kuasa atas segala sesuatunya di bumi. Kepadanya dikenakan kekuatan yang serupa dengan kekuatan Tuhan sendiri dan menurut gambar Allah dijadikanNya." (TB LAI)

7 2:23: "Sebab Allah telah menciptakan manusia untuk kebakaan, dan dijadikanNya gambar hakekat-Nya sendiri." (TB LAI)

${ }^{8}$ Lih. John P. Meier, "On the Veiling of Hermeneutics (1 Cor. 11:2-16)," The Catholic Biblical Quarterly, 40, no. 2 (April 1978): 219; David E. Garland, 1
} 
berkata: "[Paul] understands the A $\delta \alpha \mu$ of Genesis 1 in terms of the concrete individual A $\delta \alpha \mu$ of Genesis $2 . \mathrm{He}$, and he alone, is made directly by God, and is therefore the direct, precise image of God."9 Implikasi tidak langsung dari cara pembacaan ini adalah perempuan bukanlah ciptaan langsung Allah, karena hanya pria yang dibentuk langsung oleh Allah dan perempuan dibentuk dari substansi pria.

Akan tetapi, dengan ungkapan demikian, Paulus tidak sedang menyimpulkan bahwa perempuan adalah gambar dari pria. ${ }^{10}$ Dia mungkin dipengaruhi oleh tradisi rabinik yang menunjukkan bahwa perempuan bukanlah gambar Allah: Tanch B Tazria 10, ${ }^{11}$ BemR. 3:140d. ${ }^{12}$ Penafsiran ini menyebabkan masyarakat saat itu memperlakukan laki-laki dan perempuan secara hirarkis, karena pria dianggap lebih mulia sebagai ciptaan langsung Allah. Jervell mengobservasi bahwa, "the tendency of rabbinic theology is not only to deny the status of the image of God to Eve -from the standpoint of salvation history- but so to every woman." 13 Dalam lingkungan tradisi-tradisi ini, dengan tidak menyebutkan bahwa status perempuan adalah gambar Allah, tidaklah berarti bahwa Paulus setuju dengan teologi Yahudi yang mendukung inferioritas perempuan. Pertanyaan Paulus tersebut bukanlah mengenai gambar

Corinthians, Baker Exegetical Commentary on the New Testament (Grand Rapids, MI: Eerdmans, 219.

${ }^{9}$ Meier, "Hermeneutics," 219.

${ }^{10}$ Gordon D. Fee, The First Epistle to the Corinthians. The New International Commentary on the New Testament (Grand Rapids, MI: Eerdmans, 1987), 522.

11 "Eve is not created in the image of God, but created out of Adam" dikutip dari Jacob Jervell, Imago Dei: Gen I, 26 f. im Spätjudentum, in der Gnosis und in den paulinischen Briefen (Göttingen: Vandenhoeck \& Ruprecht, 1960), 110.

${ }_{12}$ Bdk. Tanch B Tazria 2 and Aggadat Bereshit 53, S. 107. Midrash Rabba Number R 3:8; Midrash Rabba Gen. R 21:5 (Before Eve was created, Adam was like an angel); lihat Jervell, Imago Dei, 110.

${ }^{13}$ Jervell, Imago Dei, 111. Ada juga pemahaman lain dari teologi rabinik yang memahami bahwa pasangan yang sudah menikah adalah gambar Allah.

Pemahaman ini tertuang dalam terjemahan Aquila, Theodosian, and Targum Jeremiah II pada Kej. 1:27 (Jervell, ibid.). 
Allah (the image of God, karena dia tidak menjelaskan pernyataannya "pria adalah gambar Allah" lebih lanjut; malahan dia menambahkan penekanan bahwa pria adalah kemuliaan Allah, dan perempuan adalah kemuliaan pria. $^{14}$ Selain itu, menurut Jervell, ide ini (perempuan bukan gambar langsung Allah) yang dicampuradukkan dengan konsep keluarga juga melihat bahwa seorang anak laki-laki merepresentasikan gambar ayahnya [karena Allah yang menciptakan Adam/manusia (Kej. 5:1)], dan bukan seorang anak perempuan yang merepresentasikan ayahnya, sehingga perempuan bukan cermin atau gambar langsung Allah. ${ }^{15}$

Hal yang menarik, pernyataan manusia atau pria sebagai kemuliaan Allah tidak terdapat dalam kitab Kejadian. Paulus mungkin sedang merujuk pada beberapa tradisi rabi yang menunjukkan bahwa Adam adalah cermin dari kemuliaan Allah. Tradisi-tradisi yang dimaksud di sini adalah "Palestinian Talmud Shabbat 2:5b; Balylonian Talmud Baba Batra 58a; Aggadic Midrash Pesigta 4:36b; 12:10a; Tanch Achare Mot 3; Midrash Rabba: Koh R 8:1; Pirqe R El 14:33b; Babylonian Talmud Chag 12a; Midrash Genesis R 12:6; Tanch Pikude 2." ${ }^{16}$ Literatur-literatur ini mewakili teologi Yahudi yang memahami bahwa pria diciptakan menurut kemuliaan Allah, dan bukan perempuan yang diciptakan menurut kemuliaan Allah, dalam kaitannya dengan konsep penciptaan pria yang sesuai dengan gambar Allah. Dengan kata lain, tradisi Yahudi menghubungkan kemuliaan dengan gambar Allah ${ }^{17}$ yang merujuk pada atribut dan kebesaran Allah, ${ }^{18}$

\footnotetext{
${ }^{14}$ Lih. Fee, Corinthians, 513; Garland, 1 Corinthians, 522; C.K. Barret, Black's New Testament Commentary: The First Epistle to the Corinthians (Peabody, MA: Hendrickson Publishers, 1968), 252.

${ }^{15}$ Jervell, Imago Dei, 111. Lihat juga Wolfgang Schrage, Der erste Brief an die Korinther, Bd.7/2:1 Kor 6,12-11,16 (Düsseldorf: Benziger Verlag, 1995), 509.

${ }^{16}$ Tradisi-tradisi ini dirangkumkan oleh Jervell, Imago Dei, 100.

${ }^{17}$ Jervell menunjukkan salah satu contoh relasi itu: "In Tanch Pikude 2 it is said that man was created, which is explained in greater detail: according to the glory of his Creator. The expression can only be understood in such a way that one can use כבוד .צלמ for the attribute of God. - Ex 23:15: Moses asked to see
} 
sehingga pria adalah refleksi kemuliaan Allah karena pria diciptakan sesuai keagungan dan kemuliaan Allah. ${ }^{19}$

Paulus tidak menjelaskan atau mengklarifikasi konsep pria sebagai refleksi kemuliaan Allah lebih lanjut kemungkinan karena ia sedang menggambarkan pemahaman umum saat itu yang tidak memerlukan penjelasan tambahan. Akan tetapi, Paulus tidak berhenti sampai di titik ini yang seolah-olah hanya mengagungkan posisi pria sebagai kemuliaan dan gambar Tuhan. Paulus menambahkan tradisi tentang perempuan adalah kemuliaan pria untuk menekankan pentingnya perempuan di dalam budaya yang menegaskan dominasi pria.

Tradisi di dalam pernyataan bahwa perempuan adalah kemuliaan pria terdapat dalam beberapa teks, seperti Amsal 11:16a

God's image, כבוד: Let me see yours, Ex 33, 18. - Adam's divine image was his כבוד, the light of the law. Gen. 1:27 corresponds to Ex 34, 29, according to Beth Ha-Midrash Tadsche 4. In Deut. Rabba 11.3 it is said that Moses and Adam discussed who was the greatest of them. Adam claims he was created. Moses then answers that Adam in his godlike Doxa, the image of God, did not remain, while he, Moses, did not lose his godlike equality." Jervell, Imago Dei, 100; tampaknya tradisi ini merupakan refleksi dari Bilangan 12:8 yang menggambarkan Musa bisa berkomunikasi langsung dengan Allah.

${ }^{18}$ Lih. A. Feuillet, "La Dignité Et Le Rôle De La Femme D'après Quelques Textes Pauliniens: Comparaison Avec L'Ancien Testament," New Testament Studies 21, no. 2 (1975): 160 dikutip oleh Anthony Thiselton, The First Epistle to the Corinthians: A Commentary on the Greek Text (Grand Rapids: MI: W. B. Eerdmans, 2000), 835. Beberapa ahli (Thiselton, Fee) mencoba melihat kemuliaan sebagai sebuah tanda kehormatan berdasarkan Maleakhi 1:6; tetapi tradisi Yahudi tidak memiliki pandangan demikian; Jervell menunjukkan bahwa teologi Yahudi somehow menghubungkan kemuliaan Adam dengan wajahnya: "[Adam] is the image of God in the glorious appearance of man, that is, on his face see BBaba B 58a; Gene R 16.1; Koh R 8, 1 S 2; BMoed Q 15b; BSanh 46 b. This also explains why the meaning can have "face", see Gene R 53.6, Tanch Wajjesheb 2, Pb 3.6a, PMoed Q 3, 83a." Jervell, Imago Dei, 103.

${ }^{19}$ Lihat juga BDAG yang memiliki pendapat sama bahwa kata kemuliaan ini lebih cenderung merujuk pada cermin/refleksi. Untuk penjelasan Bauer dkk, lihat William Arndt, Frederick W. Danker and Walter Bauer, A Greek-English Lexicon of the New Testament and Other Early Christian Literature (BDAG), 3rd ed. (Chicago: University of Chicago Press, 2000), 257. 
(LXX) ${ }^{20} 1$ Edras $4: 17 ;^{21}$ dan terdapat pada sebuah batu nisan, yang tertulis nama istri seorang Yahudi Romawi Sophronius, yang ditemukan di dalam bangunan bawah tanah (katakombe) dari Vigna Randanini (sebelah luar kota Roma). ${ }^{22}$ Tradisi-tradisi ini mengungkapkan adanya penghormatan terhadap perempuan di tengah budaya patriarkat. Dengan merujuk pada tradisi-tradisi di atas secara tidak langsung, Paulus mengingatkan pembaca bahwa karena perempuan adalah kemuliaan pria, yang merupakan kepala metaforana, dia harus membawa atau menyinarkan kemuliaan pria dengan menutup atau menudungi kepalanya dalam ibadah.

\section{Ayat 8-9}

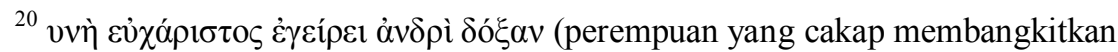
kemuliaan pada lelaki; terjemahan literal);" Septuaginta: SESB Edition, ed. Alfred Rahlfs and Robert Hanhart (Stuttgart: Deutsche Bibelgesellschaft, 2006); or Amsal 12:4 (MT).

21 “'Perempuan-perempuan] ini juga membuatkan baju untuk pria-pria; [perempuan-perempuan] ini membawa kemuliaan ( $\delta$ ó $\xi \alpha v)$ atas para pria; dan tanpa perempuan para pria tidak bisa," diambil dari R. H. Charles, Apocrypha of the Old Testament, ed. Robert Henry Charles (Bellingham, WA: Logos Research Systems, Inc., 2004), 1:31. Dalam konteks keseluruhan perikop (ayat 13-32), ayat ini berbicara mengenai pentingnya perempuan dalam kaitannya dengan para lelaki.

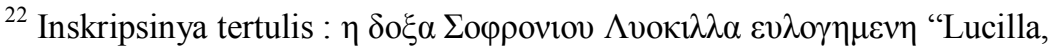
kemuliaan Sophronius yang diberkati," dikutip oleh Garland dari R. Collins (1999:410), Corinthians, 522; lihat juga Pieter W. van der Horst, Ancient Jewish Epitaphs. Contributions to Biblical Exegesis and Theology 2, ed. Tj. Baarda and A.S. van der Woude (Kampen, the Netherlands: Kok Pharos Publishing House, 1991), 143. Horst menunjukkan bahwa, "We further note that Paul's conviction that 'woman is the glory $(\delta o \xi \alpha)$ of man' (1 Cor. 11:7) is also expressed by the Roman Jew Sophronius who inscribes his wife's tombstone with the words 'the glory of Sophronius (was) the blessed Lucilla"'; ibid, note 11. Sayangnya, sejak batu tersebut hilang, Horst menambahkan, cukup sulit bagi kita untuk menemukan informasi berkaitan dengan waktu dan konteks penulisan inskripsi ini; ibid. 
Dalam dua ayat ini, Paulus menggunakan ringkasan atau ikhtisar narasi ${ }^{23}$ dari Kejadian 2 (kisah penciptaan) sebagai alat hermeneutikanya: urutan penciptaan $^{24}$ sebagai argumentasi lanjutannya berkaitan kesopanan dan penampilan dalam ibadah. Mengenai urutan penciptaan, tidak banyak tradisi dalam tulisan periode bait suci kedua yang berbicara mengenai perbandingan status perempuan dan laki-laki, hanya Philo dalam Question and Answers on Genesis 1:27 $7^{25}$ dan Sirakh 42:14. ${ }^{26}$ Kedua tulisan ini lebih menekankan tentang status perempuan yang lebih rendah daripada laki-laki. Menurut Philo, perempuan itu lebih rendah dari laki-laki karena perempuan tidak diciptakan langsung oleh Allah, berbeda dengan laki-laki dan binatang yang merupakan ciptaan

\footnotetext{
${ }^{23}$ Penulis menggunakan framework narrative summary, salah satu pendekatan lanjutan intertekstualitas yang dikemukakan dari Leonard Wee Kong-Hwee dalam desertasinya "Beyond the Echoes: Extending the framework for Biblical Intertextuality,'Durham theses, Durham University (2012), available at Durham E-Theses Online:
}

http://etheses.dur.ac.uk/6968/.

${ }^{24}$ Sebagai tambahan, ada beberapa pandangan para ahli dalam mendefinisikan urutan penciptaan: Richard Hays berpendapat bahwa urutan penciptaan adalah urutan prioritas yang bersifat ontologis; sebaliknya, Belleville melihatnya sebagai urutan kronologis; C. Blomberg dan W. Webb berpendapat bahwa urutan ini adalah urutan yang didasarkan pada analisis budaya, viz. "primogeniture or the privilege of firstborn," karena menurut mereka, Paulus berargumen berdasarkan konteks budaya (ayat 16). Lihat Richard Hays, First Corinthians: Interpretations: A Bible Commentary for Teaching and Preaching (Louisville, LV: John Knox Press, 1997), 187; Linda L. Belleville, "Teaching and Usurping Authority: 1 Timothy 2:11-15" in Discovery Biblical Equality: Complementary Without Hierarchy, ed. R.W. Pierce, R.M. Groothuis, Gordon D. Fee (Downers Grove, IL: IVP Academic, 2005), 222; Craig Blomberg, The NIV Application Commentary: 1 Corinthians (Grand Rapids, MI: Zondervan Publishing House, 1994), 216; William J. Webb, Slaves, Women And Homosexuals: Exploring The Hermeneutics Of Cultural Analysis (Downers Grove, IL: IVP Academic, 2001), 134-144.

25 "Mengapa bukan perempuan, seperti binatang lain dan lelaki, juga dibentuk dari bumi, malahan dari sisi lelaki? Pertama, karena perempuan tidak setara dalam kehormatan (honour) dengan lelaki." Philo, Supplement 1. Questions and Answers on Genesis, LCL 380, transl. Raphl Marcus (London: Harvard University Press, 1951), 16.

26 "Kejahatan laki-laki lebih baik dari pada kebajikan perempuan, dan perempuanlah yang mendatangkan malu dan nista" (TB LAI). 
langsung. ${ }^{27}$ Karena itu, dia menyimpulkan bahwa perempuan lebih rendah secara hirarki dari laki-laki dan subordinasi perempuan diterima sebagai hal yang umum atau lazim dalam dunia saat itu. Kitab Sirakh juga merefleksikan tradisi mirip yang menghirarkikan pria di atas perempuan.

Bagaimana dengan Paulus? Berbeda dari eksegesis Philo terhadap kisah penciptaan yang cenderung merendahkan perempuan, Paulus tidak memahaminya demikian, karena Paulus menekankan kesetaraan gender dalam tulisannya yang lain (bdk. Galatia 3:28; 1 Korintus 7:2-4). Dengan mengekspresikan urutan penciptaan, menurut penulis, Paulus berargumen bahwa karena laki-laki diciptakan sebelum perempuan, dan perempuan adalah penolong yang sepadan untuk pria, maka perempuan harus menudungi kepalanya. Argumentasi Paulus terlihat dari karakteristik dari ringkasan narasi berikut ini:

\section{Penyusunan Kembali Cerita pada Level Mikro (Rearrangement at Micro Level)}

Di dalam ringkasan narasi tentang kisah penciptaan kitab Kejadian 2 (ayat 8-9), Paulus tidak menyusun ringkasannya secara kronologis, sehingga hal ini disebut penyusunan atau penataan kembali pada level mikro. Contohnya, dia mengubah

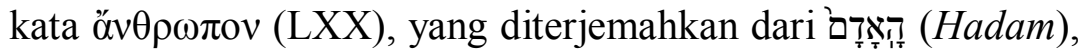
menjadi òví $\rho$, bukan hanya dalam ayat 8-9, tetapi juga dalam ayat-ayat lain di perikop yang sama (ayat 2-16). Sementara itu, ketika Paulus menggunakan argumentasi yang sama (urutan penciptaan) dalam 1 Tim $2: 13,{ }^{28}$ dia menggunakan ekspresi yang berbeda (Á̀̀̀ $\mu)$. Di samping itu, pada ayat 8 , Paulus

\footnotetext{
27 Untuk mengetahui lebih lanjut persepsi Philo terhadap perempuan, lihat Dorothy Sly, Philo's Perception of Women, Brown Judaic Studies 209 (Atlanta, GA: Scholars Press, 1990).

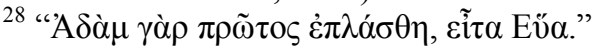


merangkum materi yang diambil dari Kejadian 2:21-23, tetapi pada ayat selanjutnya, dia kembali lagi pada Kejadian 2:18, yang tentunya tidak berurutan. Hal ini dapat dideskripsikan dalam tabel sebagai berikut:

\begin{tabular}{|c|c|c|}
\hline & $\begin{array}{c}\text { Ringkasan Narasi/cerita } \\
\text { (Summary Narrative) }\end{array}$ & Teks PL \\
\hline Ayat 8 & Perempuan diciptakan dari pria & Kej 2:21-23 \\
\hline Ayat 9 & Perempuan diciptakan untuk pria & Kej 2:18 \\
\hline
\end{tabular}

\section{Kerangka Episodik (Episodic Frames)}

Paul meringkas dan mengubah kisah penciptaan (Kejadian 2) menjadi kerangka eposide dalam bentuk dua

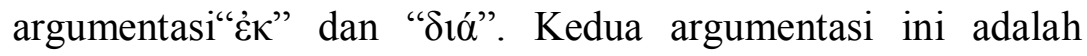
argumentasi lanjutan dari pernyataan Paul di ayat $7 \mathrm{c}$ (perempuan adalah kemuliaan laki-laki), sebagaimana permulaan ayat 8 dan 9 dimulai dengan kata penghubung ró.$^{29}$

Dalam ayat 8, Paulus menggunakan kata preposisi غ̇א atau argumentasi "dari" untuk menunjukkan elemen interpretatif bahwa pria atau manusia sudah ada ketika perempuan itu diciptakan. Dia tidak menggunakan kisah penciptaan dari Kejadian 1:27 yang mengindikasikan bahwa Allah menciptakan pria dan perempuan. Dia justru menggunakan ringkasan kisah dari Kejadian 2:7 untuk menunjukkan urutan penciptaan dengan menggunakan argumentasi "dari": perempuan diciptakan dari pria.

Dalam ayat 9, Paulus menggunakan kata preposisi $\delta \iota^{30}$ dengan merujuk pada Kejadian 2, yang di dalamnya

${ }^{29}$ Fee, Corinthians, 513.

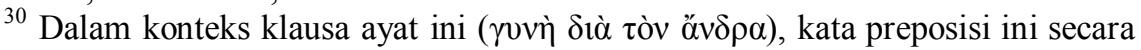
sintaks memiliki fungsi kausatif , karena memiliki deklensi akusatif sehingga 
menceritakan bahwa Hawa ditunjuk sebagai penolong yang sepadan untuk Adam. Dalam konteks 1 Kor. 11:9, Paulus menggunakan kisah itu untuk mendukung argumennya bahwa perempuan adalah kemuliaan pria/laki-laki (ayat 7c). ${ }^{31}$ Tabel berikut meringkaskan perkembangan argumentasi Paulus:

\begin{tabular}{|c|c|c|c|}
\hline & $\begin{array}{c}\text { Perkembangan } \\
\text { argumentasi }\end{array}$ & $\begin{array}{c}\text { Ringkasan } \\
\text { narasi }\end{array}$ & Narasi PL \\
\hline Ay. 8 & $\begin{array}{l}\text { Argumentasi } \\
\text { "dari" }\end{array}$ & $\begin{array}{c}\text { Perempuan } \\
\text { diciptakan dari } \\
\text { pria, bukan } \\
\text { pria dari } \\
\text { perempuan }\end{array}$ & Kej 2:21-23 \\
\hline Аy. 9 & $\begin{array}{l}\text { Argumentasi } \\
\text { "untuk" }\end{array}$ & $\begin{array}{c}\text { Perempuan } \\
\text { diciptakan } \\
\text { untuk pria, } \\
\text { bukan pria } \\
\text { untuk } \\
\text { perempuan }\end{array}$ & Kej 2:18 \\
\hline
\end{tabular}

Selain argumentasi "dari" dan "untuk", Paulus juga menunjukkan kontras argumentasi dengan menggunakan adversatif kuat $\dot{\alpha} \lambda \lambda \dot{\alpha}$ untuk memperkuat argumentasinya. Sebagai contoh, dalam ayat 8 , dia menunjukkan kontras argumentasi "dari" tentang urutan penciptaan, dan dia mengulanginya dalam nuansa negatif. Pola ini diulang dalam ayat 9. Repetisi ini (bukan pria dari/untuk perempuan) digunakan dengan tujuan untuk menekankan klausa

berarti karena; lihat Andreas J. Köstenberger, Benjamin L. Merkle, and Robert L. Plummer, Going Deeper with New Testament Greek: An Intermediate Study of the Grammar and Syntax of the New Testament (Nashville, TN: B\&H Academic, 2016), 402; Daniel B. Wallace, Greek Grammar Beyond the Basics - Exegetical Syntax of the New Testament (Zondervan Publishing House, 2002), 369.

${ }^{31}$ Fee, Corinthians, 517. 
sebelumnya (perempuan diciptakan dari pria), karena mereka memiliki arti yang sama dengan klausa sebelumnya itu.

\section{Tujuan Retoris (Rhetorical Purpose)}

Ringkasan narasi Paulus memiki tujuan retoris, yang dapat dilihat dari dua cara: fokus yang selektif dan elemen yang interpretatif:

a. Fokus yang Bersifat Selektif (Selective Focus)

Dalam memilih ringkasan narasi/cerita, Paulus cukup selektif. Dia tidak memilih cerita penciptaan dari Kejadian 1 yang menjelaskan bahwa Allah menciptakan pria dan perempuan (Kejadian 1:27), tetapi dari Kejadian 2. Dia juga tidak menggunakan urutan penciptaan dari Kejadian $1,{ }^{32}$ dan menghindari deskripsi detil tentang penciptaan taman dan situasi di dalamnya (Kejadian 2:8-14), serta relasi antara pria dan perempuan itu (ayat 23-25). Fokus yang selektif dari ringkasannya digunakan untuk menunjukkan urutan penciptaan Paulus hanya diambil dari kisah penciptaan Kejadian 2.

b. Elemen yang Bersifat Interpretatif (Interpretative Element)

Dalam mendeskripsikan urutan penciptaan, Paulus memasukkan elemen yang interpretatif sebagai bagian dari argumentasinya dengan menggantikan kata őv $\theta \rho \omega \pi \mathrm{ov}$ menjadi $\alpha v \eta ́ \rho$. Apakah Paulus tidak sengaja melakukan kesalahan dengan mengubah kata ini? Penyalin $\mathfrak{p}^{46}$ sepertinya berpikir demikian dan mencoba menyelesaikan isu tekstual ini dengan mengubah kata ini kembali pada

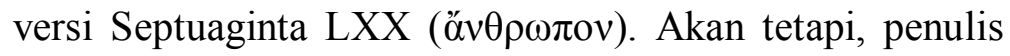

\footnotetext{
${ }^{32}$ Dalam Kejadian 1, binatang dan ciptaan lainnya secara kronologis diciptakan sebelum manusia, yang mengimplikasikan bahwa urutan penciptaan tidak harus berarti hirarki; lihat Blomberg, Corinthians, 216.
} 
yakin bahwa Paulus sengaja menggunakan kata ỏví $\rho$ daripada kata öv $\theta \rho \omega \pi \circ v$.

Berdasarkan konteks perikop (ayat 2-16) dan gaya menulis Paulus, di satu sisi, ada empat belas kali kemunculan $\grave{\alpha} v \eta \rho^{33}$ dalam Korintus: empat kali di pasal 7 di dalam konteks hubungan suami-istri (kehidupan pernikahan); delapan kali di 11:2-16; dan sekali dalam 13:11. Di sisi lain, Paulus juga menggunakan kata ǒv $\theta \rho \omega \pi$ ○ sebanyak tiga kali: 3:3; 9:8 dan 15:32 (di dalam arti yang lebih umum, yaitu manusia). Jika Paulus bermaksud merujuk obyek argumentasinya pada manusia secara umum, dia akan memilih menggunakan kata

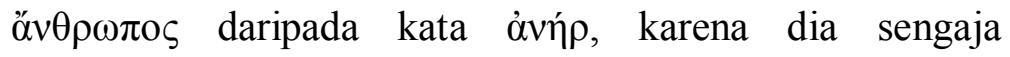
menggunakan kata ő $v \theta \omega \pi$ o juga dalam perikop-perikop lainnya di 1 Korintus. Bagi penulis, Paulus tidak salah atau dengan sengaja menggunakan kata $\alpha v \eta ́ \rho$. Pertanyaan lain

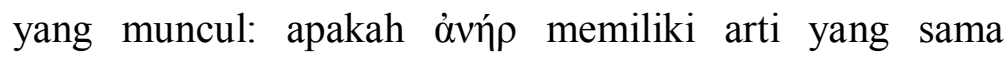
dengan ״̌ $\alpha \theta \rho \omega \pi \varsigma$ ? Bauer mengamati adanya pergeseran makna dari penggunaan ỏví $\rho$, yaitu dari penggunaan umum (manusia atau pria yang dikontraskan dengan perempuan) menjadi suami dalam zaman Paulus. ${ }^{34}$ Hal ini berarti makna òví $\rho$ di masa Paulus sudah cenderung dipahami sebagai suami pada zaman Paulus. Dengan kata lain, pilihan Paulus untuk menggunakan kata ỏví daripada kata ö $v \theta \rho \omega \pi$ o dalam konteks cerita Kejadian yang sedang dia rujuk merefleksikan penekanan interpretatifnya. Karena dia tidak merujuk pada manusia secara umum, Paulus sengaja menempatkan kontras antara

${ }^{33} 1$ Korintus 7:3, 4, 14, 39; 11:3, 4, 7, 8, 9, 11, 12, 14; 13:11.

${ }^{34}$ Bdk. Mt 1:16, 19; Mk 10:2, 12; Lk 2:36; J 4:16ff; Kis 5:9f; Ro 7:2f; 1 Kor 7:2ff, 10ff; 14:35; Gal 4:27; Eph 5:22ff; Kol 3:18f; 1 Ti 3:2, 12; 5:9; Tit 1:6; Homer et al.; Diodurus Siculus 2, 8, 6; Sir 4:10; Jos., Ant. 18, 149; Aristides 12, 2; Fragment Milne p. 74 ln. 3; Just., A II, 2, 5ff; untuk data yang lebih lengkap lihat Bauer dkk, BDAG, 79. 


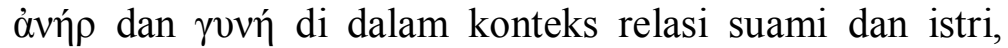
sebagaimana dia sudah mendahului menggunakan argumentasinya dalam konteks itu pada ayat 3 bahwa

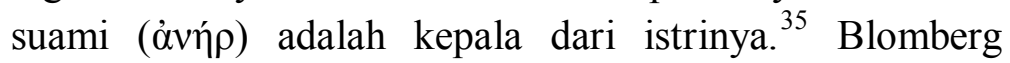
sejalan dengan pemahaman ini: "References to the creation of man and woman (vv. 8-9) have understandably given rise to the former translation [man and woman], but Adam and Eve were not only the prototypical male and female but also the first "married" couple." 36 Tentu saja tidak perlu menerjemahkan $\alpha \dot{v} \eta \dot{\rho}$ sebagai suami pada setiap ayat dalam perikop ini (ayat 2-16), karena Paulus berdiskusi tentang problem lajang dan janda dalam pasal 7 yang memahami bahwa tidak setiap perempuan dalam gereja Korintus telah menikah. ${ }^{37}$

Di dalam ekspresi òví $\rho$ dan $\gamma v v \eta ́$ bersama pada ayat 8-9, Paulus mungkin membatasi aplikasi/penggunaan urutan penciptaan dalam kaitannya dengan konteks sebelumnya, yaitu urutan kediaman "order of the home" (ayat 3). ${ }^{38}$ Hal ini sesuai dengan logika dan tujuan retoris Paulus. Sebagaimana suami adalah kepala dari istrinya (ayat 3), suami memiliki otoritas atas istri, dan menudungi kepala adalah simbol ketaatan istri. Meskipun menudungi kepala adalah budaya yang tidak diwajibkan bagi para perempuan di Korintus, ${ }^{39}$ prinsip ini tidak dimengerti oleh

\footnotetext{
${ }^{35}$ RSV dan NRSV sepakat menerjemahkan demikian.

${ }^{36}$ Blomberg, 1 Corinthians, 209.

${ }^{37}$ Blomberg, 1 Corinthians, 209.

${ }^{38}$ Ketika mendiskusikan ayat 7, Fee juga mendeteksi hubungan antara ayat 8-9 and ayat 3; Fee, Corinthians, 515.

39 Thompson dalam studi arkeologinya mengenai lukisan dinding Pompeii yang terkubur pada $79 \mathrm{M}$ menyimpulkan bahwa tradisi menutupi/menudungi kepala adalah tradisi pilihan atau bukanlah kewajiban bagi para perempuan dalam dunia Yunani-Romawi pada masa Paulus. Untuk penjelasan lebih lanjut, lihat Cynthia L. Thompson, "Hairstyles, Head-coverings, and St. Paul: Portraits from Roman Corinth,” Biblical Archeologist 51 (2, June 1988): 112.
} 
para lajang atau janda, penulis setuju dengan Keener yang mengamati bahwa tujuan Paulus ini adalah mempraktikkan pengorbanan diri (self-sacrifice) atau "surrendering one's own right to avoid causing others to lose faith in Christ". 40 Menudungi kepala adalah manifestasi sikap berkorban demi kehidupan komunitas bersama. Hal ini sesuai dengan respons Paulus terhadap beberapa isu gereja Korintus dalam beberapa perikop lain. Contohnya, Paul menasihati saudara yang kuat mengorbankan hak mereka pada saudara yang lebih lemah berkaitan dengan isu memakan makanan yang dipersembahkan pada berhala (pasal 8), dan dalam pasal 9 Paulus mengorbankan haknya sendiri sebagai seorang rasul. ${ }^{41}$ Karena itu, dengan mengenakan kerudung kepala, para perempuan menunjukkan kasih Kristus yang berkorban, dan mereka berkontribusi pada kesatuan gereja.

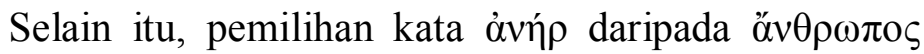
dari Paulus juga merefleksikan konteks budaya dari komunitas saat itu, yakni relasi suami-istri menjadi pola bagi relasi pria-perempuan, bahkan untuk pria dan perempuan yang tidak menikah. ${ }^{42}$ Meskipun otoritas dilaksanakan atau diekpresikan secara penuh oleh suami dan istri dalam konteks pernikahan (suami memiliki otoritas atas istri), pria yang tidak menikah dalam komunitas juga memiliki tanggung jawab ini, dan para perempuan juga memiliki tanggung jawab untuk taat di bawah otoritas pria dalam komunitas. Hal ini didasarkan pada struktur sosial dalam dunia Yunani-Romawi kuno. Para perempuan yang tidak menikah (para lajang dan

${ }^{40}$ Keener, Paul, Women and Wives, 41.

${ }^{41}$ Keener, Paul, Women and Wives, 41.

${ }^{42}$ Michael R. Riley, "The Proper Translation of Aner and Gune in the New

Testament," (paper presented for the Manitowoc Pastoral Conference, St. John's, Newtonburg, April 19, 1993). 
janda) tidak independent, tetapi tetap berada di bawah otoritas ayah mereka atau anggota keluarga lelaki yang memiliki responsibilitas setelah ayah mereka. ${ }^{43}$ Dengan kata lain, Paulus menasihatkan para perempuan untuk mengikuti tradisi ini (otoritas pria berdasarkan pola pernikahan) dengan menutupi kepala mereka pada saat itu demi kepentingan komunitas mereka, bahkan ketika mereka diikat oleh peraturan sosial untuk melakukan hal itu. Karena itu

\section{KESIMPULAN}

Pembacaan intertekstual terhadap 1 Kor. 11:7-9 menghasilkan pemahaman yang mendalam dan kaya mengenai penggunaan teks Kejadian oleh Paulus yang di dalam lingkungan tradisi teks Yahudi yang merefleksikan tradisi Kejadian. Ada beberapa pengamatan yang dapat ditarik dari hubungan intertekstual ini:

1. Secara umum, Paulus tampaknya mengikuti tradisi rabinik dan Yahudi yang bersandar pada tradisi Kitab Kejadian, yang menekankan subordinasi kaum perempuan di bawah otoritas pria (di dalam konteks urutan penciptaan), tetapi tentunya dia memberikan klarifikasi dengan menambahkan pemahaman tentang pentingnya perempuan di tengah budaya itu. Dengan kata lain, Paulus tidak menentang tradisi menutup kepala (khususnya di ayat 7), tapi tidak mengikuti sepenuhnya, karena dia menekankan pentingnya perempuan di dalam tradisi patriarkat. Selain itu, tujuan utama Paulus dengan rujukannya pada tradisi ini adalah untuk mendukung argumentasi tentang menutupi kepala perempuan di dalam ibadah. Sama halnya

\footnotetext{
${ }^{43}$ Riley, Aner and Gune; see also Michael Marlowe, "The Woman's Headcovering: 1 Corinthians 11:2-16," October 2008, accessed April 17, 2018, http://www.bible-researcher.com/headcoverings.html\#note3.
} 
juga dengan urutan penciptaan (ayat 8-9) dipakai Paulus untuk mendukung argumentasi Paulus di dalam konteks budaya yang tidak diaplikasikan ke dalam semua konteks (transcultural).

2. Ringkasan narasi Paulus di dalam ayat 8-9 adalah hal yang unik, karena dia menempatkan argumentasi dari urutan penciptaan di dalam implikasi yang kontekstual. Dia menaruh logika urutan penciptaan di dalam konteks pernikahan, yang sesuai dengan latar belakang budaya sosial jemaat saat itu (tudung kepala). Dengan menganalisa ringkasan narasi Paulus (narrative summary), kita dapat menyimpulkan bahwa urutan penciptaan ini digunakan Paulus untuk menunjukkan bahwa otoritas suami atas istri di dalam pernikahan menjadi semacam pola untuk relasi pria dan perempuan di dalam komunitas. Selain itu, pola ini menjadi alasan bagi perempuan untuk menutupi kepala mereka sebagai tanda dari kemuliaan pria di dalam komunitas. Di samping itu, dengan berargumen dari urutan penciptaan, Paulus memanggil para perempuan untuk mempraktikkan kasih dalam bentuk pengorbanan diri demi keutuhan dan kesatuan komunitas dengan menutupi kepala mereka.

3. Kita tetap harus ingat bahwa Paulus tidak menitikberatkan posisi para pria, tetapi mengkualifikasi argumentasinya dengan menjelaskan relasi interdependensi (kesaling-bergantungan) antara pria dan perempuan di dalam ayat 11-12, dan di dalam konteks sebelumnya (7:1-9) yang menunjukan relasi yang saling bergantung antara suami dan istri. Dengan kata lain, tujuan Paulus di sini tidaklah mendukung keadaan/martabat perempuan yang rendah (inferiority of women). Tujuannya jelas di dalam ayat 7-9, seperti yang diutarakan Garland: "Woman, whose head is man and who represents his glory, is 
to be covered in worship. To do otherwise brings shame to their respective heads." 44

4. Relevansi pastoral: dari pengamatan di atas, penulis melihat bahwa pendekatan Paulus dalam memecahkan masalah di gereja Korintus adalah pendekatan yang moderate. Paulus tidak memberontak atau melabrak sistem yang ada (budaya patriarkat berdasarkan urutan penciptaan), tetapi di dalam tradisi yang dominan dan tidak menguntungkan posisi perempuan, dia berusaha memberikan alasan positif berdasarkan tradisi yang berimbang (perempuan adalah kemuliaan pria), tentunya di dalam konteks meneladani kasih Kristus. Dengan demikian, dengan menudungi kepala mereka, para perempuan tidak menjadi batu sandungan bagi jemaat, dan mereka berkontribusi pada kesatuan tubuh Kristus.

\section{DAFTAR RUJUKAN}

Barret, C.K. Black's New Testament Commentary: The First Epistle to the Corinthians. Peabody, MA: Hendrickson Publishers, 1968.

Belleville, Linda L. "Teaching and Usurping Authority: 1 Timothy 2:11-15" in Discovery Biblical Equality: Complementary Without Hierarchy. Edited by R.W. Pierce, R.M. Groothuis, Gordon D. Fee. Downers Grove, IL: IVP Academic, 2005.

Blomberg, Craig. The NIV Application Commentary: 1 Corinthians. Grand Rapids, MI: Zondervan Publishing House, 1994.

${ }^{44}$ Garland, Corinthians, 522. 
Fee, Gordon D. The First Epistle to the Corinthians. The New International Commentary on the New Testament. Grand Rapids, MI: Wm. B. Eerdmans Publishing Co., 1987.

Feuillet, A. "La Dignité Et Le Rôle De La Femme D'après Quelques Textes Pauliniens: Comparaison Avec L'Ancien Testament." New Testament Studies 21, no. 2 (1975): 157191.

Fishbane, Michael. Biblical Interpretation in Ancient Israel. New York, NY: Oxford University Press, 1985.

Garland, David E. 1 Corinthians. Baker Exegetical Commentary on the New Testament. Grand Rapids, MI: Baker Academic, 2003.

Gregg, J. A. F. The Wisdom of Solomon in the Revised Version with Introduction and Notes, The Cambridge Bible for Schools and Colleges. Cambridge: Cambridge University Press, 1922), 21.

Hays, Richard B. First Corinthians: Interpretations: A Bible Commentary for Teaching and Preaching. Louisville, LV: John Knox Press, 1997.

Horst, Pieter W. van der. Ancient Jewish Epitaphs. Contributions to Biblical Exegesis and Theology 2. Edited by Tj. Baarda and A.S. van der Woude. Kampen, the Netherlands: Kok Pharos Publishing House, 1991.

Jervell, Jacob. Imago Dei: Gen I, 26 f. im Spätjudentum, in der Gnosis und in den paulinischen Briefen (Göttingen: Vandenhoeck \& Ruprecht, 1960. 
Keener, Craig S. Paul, Women and Wives: Marriage and Women's Ministry in the Letters of Paul. Grand Rapids, MI: Baker Academic, 2004.

Marlowe, Michael. "The Woman's Head Covering: 1 Corinthians 11:2-16," October 2008. Accessed April 17, 2018. Http://www.bible-researcher.com/headcoverings.html\#note3.

Meier, John P. "On the Veiling of Hermeneutics (1 Cor. 11:2-16)." The Catholic Biblical Quarterly, 40, no. 2 (April 1978): 212226.

Riley, Michael R. "The Proper Translation of Aner and Gune in the New Testament." Paper presented for the Manitowoc Pastoral Conference, St. John's. Newton burg. April 19, 1993.

Schrage, Wolfgang. Der erste Brief an die Korinther, Bd.7/2:1 Kor 6,12-11,16. Düsseldorf: Benziger Verlag, 1995.

Sly, Dorothy. Philo's Perception of Women, Brown Judaic Studies 209. Atlanta, GA: Scholars Press, 1990.

Thiselton, Anthony C. The First Epistle to the Corinthians: A Commentary on the Greek Text. Grand Rapids: MI: W. B. Eerdmans, 2000.

Thompson, Cynthia L. "Hairstyles, Head-coverings, and St. Paul: Portraits from Roman Corinth." Biblical Archeologist 51 (2, June 1988): 99-115.

W. Arndt, F. W. Danker, \& Bauer, W. A Greek-English lexicon of the New Testament and other early Christian literature. "Based on Walter Bauer's Griechisch -deutsches Wrterbuch zu den Schriften des Neuen Testaments und der frhchristlichen 
[sic] Literatur, sixth edition, ed. Kurt Aland and Barbara Aland, with Viktor Reichmann and on previous English editions by W.F. Arndt, F.W. Gingrich, and F.W. Danker.", 3rd ed. Chicago: University of Chicago Press, 2000.

Wallace, Daniel B. Greek Grammar Beyond the Basics - Exegetical Syntax of the New Testament. Zondervan Publishing House and Galaxie Software, 1999; 2002.

Webb, William J. Slaves, Women and Homosexuals: Exploring the Hermeneutics of Cultural Analysis. Downers Grove, IL: IVP Academic, 2001. 